\title{
PENETAPAN UPAH MINIMUM KOTA PALEMBANG TAHUN 2016 \\ DALAM PERSPEKTIF EKONOMI SYARI'AH
}

\author{
Hana Pertiwi \\ Program Pascasarjana \\ Universitas Islam Negeri Raden Fatah Palembang \\ E-mail: hanatiwi47@gmail.com
}

\begin{abstract}
Islam commands people to seek a job in meeting the needs of life, in way can benefit those who seek. in this research is the study subject " minimum wage in the city of palembang in 2016 sharia economic perspective" the formulation of the problem how the principles remuneration according to shariah economics, how the mecanism for setting the minimum wage the city of palembang in accordance with economic prinsiple, and what are the implications for the welfare of the city minimum wage workers in the city of Palembang. This research is a field research, which was conducted using qualitative. The source of this study are primari and secondary. Techniques in this study is observation, interview and documentation. The method used in this research is normative juridical approach that is supported by empirical juridical approach.
\end{abstract}

Keywords: wage, islamic law and the welfare of humen life

\begin{abstract}
Abstrak
Islam memerintahkan orang untuk mencari pekerjaan dalam memenuhi kebutuhan hidup, dengan cara dapat menguntungkan orang-orang yang mencari. Dalam penelitian ini adalah subjek penelitian "upah minimum di kota palembang pada tahun 2016 perspektif ekonomi syariah" perumusan masalah bagaimana asas remunerasi menurut ekonomi syariah, bagaimana mecanisme penetapan tarif minimum kota palembang sesuai dengan Prinsiple ekonomi, dan apa implikasinya bagi kesejahteraan pekerja upah minimum kota di kota Palembang. Penelitian ini merupakan penelitian lapangan yang dilakukan secara kualitatif. Sumber penelitian ini adalah primari dan sekunder. Teknik dalam penelitian ini adalah observasi, wawancara dan dokumentasi. Metode yang digunakan dalam penelitian ini adalah pendekatan yuridis normatif yang didukung oleh pendekatan yuridis empiris.
\end{abstract}

Kata kunci: Upah, hukum islam dan kesejahteraan hidup manusia

Dengan memenuhi kebutuhan hidup manusia, para pekerja melakukan kegiatannya berdasarkan apa yang sudah menjadi tanggungjawabnya sebagai buruh atau karyawan, akan tetapi terkadang apa yang sudah dilakukan tidak seimbang dengan apa yang diperoleh. Sehingga tidak dapat dengan sepenuhnya memenuhi kebutuhan hidup. Yang mana pekerja 
mempunyai haknya yaitu untuk memperoleh pekerjaan, hak atas upah sesuai dengan perjanjian, diperlakukan secara baik dalam lingkungan pekerjaan, hak atas jaminan sosial (Lubis, 2014: 166). Pokok pangkal ketidakpuasan buruh dalam pengupahan antara lain lambatnya pelaksanaan pembayaran upah, adanya pemotongan-pemotongan upah untuk keperluan suatu dan bagi kepentingan buruh, tanpa perundingan dulu dengan pihak buruh, adanya kehendak dari pihak buruh agar upahnya dipersamakan dengan pengupahan yang lebih baik dari perusahaan lain.

Buruh menilai kondisi kehidupan mereka saat ini masih memprihatinkan, mereka menganggap upah yang diterima belum sesuai dengan tuntutan dan hak-hak buruh. Bahkan upah minimum yang diterima sulit unutk memenuhi kebutuhan pokok buruh dan keluarga mereka sehari-hari. Meskipun upah minimum setiap tahunnya mengalami kenaikan masih belum memenuhi kebutuhan pokok buruh dan keluarga.

Kaum buruh merasa posisi mereka terus termarjinalkan, peran buruh masih dijadikan sebatas instrumen unsur produksi pada sistem ekonomi. Dengan upah minimum terus menaglami kenaikan sesuai dengan perkembangan daya beli masyarakat. Namun hal tersebut, persentase kenaikan upah tersebut tidak memiliki korelasi kuat dengan meningkatkan kebutuhan buruh dan masyarakat (Iskandar, 2004: 84).

Pembatasan penawaran tiap tingkat kualitas tenaga kerja dibanding semua faktor produksi lainnya diperkirakan akan meningkatkan upah, penambahan tenaga kerja dalam hal yang lainnya tetap, cenderung menekan tingkat upah kebawah (Nordhaus, 1986: 281). Dengan demikian penetapan upah dapat dilakukan berdasarkan ketentuan yang sudah berlaku dan bisa memenuhi kebutuhan yang layak bagi pekerja/buruh.

Sejak diberlakukannya Otonomi Daerah sesuai dengan ketentuan Undang-undang Nomor 32 tahun 2004 tentang Pemerintahan Daerah, dan sesuai dengan bunyi pasal 1 angka (3) Pemerintah daerah adalah Gubernur, Bupati atau Walikota, dan perangkat daerah sebagai unsur penyelenggara pemerintahan daerah, angka (5) Otonomi daerah adalah hak, wewenang, dan kewajiban daerah otonom untuk mengatur dan mengurus sendiri urusan pemerintahan dan kepentingan masyarakat setempat sesuai dengan peraturan perundang-undangan, (7) Desentralisasi adalah penyerahan wewenang pemerintahan oleh Pemerintah kepada daerah otonom untuk mengatur dan mengurus urusan pemerintahan dalam sistem Negara Kesatuan Republik Indonesia.

Hukum Islam juga mengatur tentang upah pekerja dalam konsep Ijarah. Ijarah dalam Islam ada dua macam yaitu Ijarah terhadap pemanfaatan dan Ijarah terhadap pekerjaan. Disini penulis membahas tentang Ijarah terhadap pekerjaan karena menyangkut upah yang diberikan. Sebagai contoh ijarah terhadap suatu pekerjaan tertentu seperti mengupah seseorang untuk membangun suatu bangunan, mengupah seseorang untuk menjahit baju, mengupah seseorang untuk mengangkut barang ketempat tertentu, mengupah seseorang untuk mewarnai kain, mengupah seseorang untuk memperbaiki sepatu dan sebagainya berupa pekerjaan-pekerjaan yang boleh mengupah seseorang untuk melakukannya.

Penetapan upah minimum Kota Palembang dilakukan oleh bidang hubungan industrial syarat kerja dan kesejahteraan pekerja. Penelitian tentang mekanisme penetapan upah minimum Kota Palembang dilakukan dengan cara mengumpulkan data/dokumen melalui wawancara kepada informan yang telah ditentukan dan melakukan observasi lapangan. Hal 
ini bertujuan agar hasil analisis ini nantinya dapat terarah dan dapat menemukan solusi pemecahan permasalahan penetapan upah minimum Kota Palembang ditinjau dalam perspektif ekonomi syariah.

Upah berasal dari kata "al-ajru” yang bearti "al-iwadlu” (ganti), upah atau imbalan (Ghazaly, 2010: 277). Menurut Afzalurrahman (2000: 295) upah adalah harga tenaga kerja yang dibayarkan atas jasa-jasanya dalam produksi. Sedangkan Hafiduddin dan Tanjung menyatakan upah adalah imbalan yang diterima seseorang atas bentuk pekerjaannya dalam bentuk imbalan materi di dunia (adil dan layak) dan dalam bentuk imbalan pahala di akhirat (imbalan yang lebih baik). Dalam Islam upah merupakan salah satu unsur ijarah (Mas'adi, 2002: 182), selain tiga unsur lainnya: aqid (orang yang berakad), ma'qud'alaih (barang yang menjadi objek akad), dan manfaat.

Berdasarkan ketentuan pasal 1 angka 30 Undang-Undang Nomor 13 Tahun 2003, yang berbunyi: "Upah adalah hak pekerja/buruh yang diterima dan dinyatakan dalam bentuk uang sebagai imbalan dari pengusaha atau pemberi kerja kepada pekerja/buruh yang ditetapkan dan dibayarkan menurut suatu perjanjian kerja, kesepakatan, atau peraturan perundang-undangan, termasuk tunjangan bagi pekerja/buruh dan keluarganya atas suatu pekerjaan dan/atau jasa yang telah atau akan dilakukan" (Asri, 2009: 107).

Definisi lain menyebutkan bahwa istilah (wage) dan gaji (salary) menggambarkan banyakanya variasi dalam metode pembayaran. Dalam penggunaan yang sudah umum, upah adalah pembayaran yang diberikan kepada karyawan produksi dengan dasar lamanya jam kerja. Gaji adalah pembayaran yang diberikan kepada pegawai tata usaha, pengawas dan manajerial. Upah dibayarkan kepada mereka yang biasanya tidak mempunyai jaminan pekerjaan secara terus menerus sepanjang minggu, bulan atau tahun. Gaji adalah imbalan jasa yang dibayarkan atau diperhitungkan secara bulanan atau tahunan (Moekijat, 1987: 6). Perbedaan ini tidak mutlak dalam tahun-tahun belakangan ini beberapa perusahaan memberikan gaji kepada pegawai-pegawai tetap atau pegawai-pegawai tidak dalam percobaan. Pendapatan adalah upah yang sebenarnya dikurangi dengan lembur, uang jasa, komisi dan faktor-faktor lainnya.

Dapat disimpulkan upah adalah imbalan yang berupa uang yang diberikan kepada pekerja yang telah memenuhi kewajibannya untuk kelangsungan hidup.

\section{Hukum Islam dan Kemaslahatan Hidup Manusia}

Adapun 'urf menurut syara' dalam kajian ushul fiqh ialah, suatu kebiasaan msyarakat yang dapat dipatuhi dalam kehidupan mereka sehingga mereka merasa tentram. Kebiasaan yang telah berlangsung lama dapat berupa ucapan dan perbuatan, baik bersifat khusus maupun bersifat umum. 'urf adalah suatu yang telah menjadi kebiasaan dan diterima oleh tabiat yang baik dengan tidak bertentangan dengan syariat Islam.

Dalam hal penentuan upah, Islam tidak menetapkan harga yang khusus dalam upah seorang pekerja, tetapi usaha-usaha itu harus memenuhi hak-hak keadilan dan juga harus memperhatikan kualitas kerja, kepentingan dan ukuran tanpa ada didalamnya kekeliruan yang berlebihan (Al-Ibrahimi, tt: 60). Upah merupakan muamalah yang telah disyariatkan dalam Islam, hukum asalnya menurut jumhur ulama boleh atau mubah sesuai dengan ketentuan yang 
ditetapkan oleh syara' berdasarkan al-Qur'an, hadits dan ketentuan para ulama (Al-Juhaili, 2005: 3801).

Tujuan syari' dalam penentuan hukum Islam yaitu merealisir kemaslahatan manusia dengan menjamin kebutuhan pokoknya (dharuriyah) dan memenuhi kebutuhan sekunder (hajiyat), serta pelengkap mereka (tahsiniyat). Menurut al-Syatibi mengklasifikasikan seluruh kebutuhan dalam kajian Islam terkait dengan dan penciptaan kemaslahatan agama dan kehidupan dunia termasuk dalam kategori mubah terbagi menjadi dharuriyah, hajiyat, dan tahsiniyat.

Menurut al-Ghazali kebutuhan manusia itu terdiri atas tiga yaitu kebutuhan primer (dharuriyat), sekunder (hajiyat), dan perlengkapan mewah (tahsiniyat) (Zainidin, tt: 44).

Dengan demikian jelas bahwa perlunya kebutuhan primer (dharuriyat),sekunder (hajiyat), dan perlengkapan mewah (tahsiniyat). Adapun ketentuan upah Minimum Kota Palembang dan mekanisme penetapannya dalam pandangan hukum Islam merupakan aplikasi dari teori maslahah dan urf.

Teori maslahah sebagai acuan penetapan Upah miinimum Kota Palembang artinya tidak ada nash dari al-Qur'an dan as-Sunnah yang menjelaskan upah secara tekstual. Tetapi berdasarkan pendekatan turunnya hukum syar'i yaitu memlihara tujuan hukum Isalm berdasarkan muqasid al-syaria'ah yang memiliki tujuan utama untuk menghadirkan maslahah yakni kebaikan dan kesejahteraan manusia. Upah merupakan manifestasi memelihara harta (al-mal) dalam al-dharuriyah al-kams. Kemudian bentuk maslahah terimplementasi pada ketentuan Upah Minimum dalam peraturan Pemerintah Nomor 78 Tahun 2015 tentang pengupahan, yaitu penetapan upah dilakukan berdasarkan Inflasi nasional dan pertumbuhan produk domestik bruto (PDB), pertumbuhan ekonomi serta sebagai perbandingan Kebutuhan Hidup Layak (KHL). Dalam Islam, upah merupakan salah satu unsur ijarah selain tiga unsur aqid (orang yang berakad), ma'qud (barang yang menjadi objek akad), dan manfaat. Kemudian konsep upah dalam Islam menggunakan bingkai moralitas. Upah harus seimbang antara dunia dan akhirat dalam penetapannya harus sesuai dengan apa yang dikerjakan, Islam menginginkan agar seseorang bekerja menerima uipah yang layak, tidak kurang dari kebutuhan sehari-hari.

Maka sebelum bekerja perlu ada perjanjian antara kedua belah pihak sehingga tidak ada perselishan antara keduanya. Umat Islam pada masa sahabat berijma' bahwa Ijarah adalah boleh, karena manusia membutuhkan kemanfaatan suatu barang seperti kebutuhan mereka kepada barang itu sendiri. Akan tetapi, syara' merupakan sejumlah jaminan terhadap hak ajiir (orang yang dipekerjakan dengan upah), yaitu kerelaan dan persetujuan, keadilan atau propesionalitas, dan urf (kebiasaan yang berlaku, common law). Oleh sebab itu, upah harus adil sesuai dengan kebiasaan yang berlaku dengan mempertimbangkan bentuk keahlian, serta harus dilakukan atas dasar kebebasan, kerelaan dan atas kemauan sendiri tanpa ada suatu bentuk pemaksaan (Az- Zuhaili, 2011: 84).

Syariat Islam menganjurkan agar upah yang diterima oleh tenaga kerja, sesuai dengan tenaga yang telah diberikan. Tenaga kerja tidak boleh dirugikan, ditipu dan eksploitasi tenaganya, karena mengingat keadaan sosial tenaga kerja berada pada posisi perekonomian lemah. Gaji harus dibayar atau dihargai sesuai dengan keahlian dan skill masing-masing pekerja. 
Dalam penetapan upah minimum terdapat prinsip-prinsip yang menurut Moekiyat dapat dijadikan dasar pertimbangan dalam penentuan besaran upah minimum tersebut; 1) Upah yang diberikan harus cukup untuk hidup pekerja dan keluarganya dengan kata lain besarnya upah harus memenuhi kebutuhan minimum; 2) Pemberian upah harus adil, artinya besarnya upah harus tergantung pada berat ringannya kewajiban dan tanggungjawab yang dibebankan kepada pekerja yang bersangkutan. Pekerja yang pekerjaannya sulit tanggungjawabnya berat harus diberi upah yang lebih besar dari pada pekerja/buruh yang kewajiban dan tanggungjawabnya ringan; 3) Upah harus diberi tepat pada waktunya, supaya mengurangi produktivitas kerja; 4) Besar kecilnya upah harus mengikuti perkembangan harga pasar, hal ini perlu diperhatikan karena yang penting bagi pekerja bukan banyaknya uang yang diterima tetapi berapa banyak barang-jasa yang dapat diperoleh dengan jasa tersebut. Jadi yang terpenting upah riil bukan nominal; 5) Sistem pembayaran upah harus mudah dipahami dan dilaksanakan sehingga pembayaran dapat dilakukan dalam waktu yang relatif singkat; 6) Perbedaan dalam tingkat upah harus didasarkan atas evaluasi jabatan objektif; 7) Struktur upah harus ditinjau kembali dan mungkin diperbaiki apabila kondisi berubah.

Islam menawarkan suatu penyelesaian yang baik atas masalah upah dan menyelamatkan kepentingan dua belah pihak, yakni buruh dan pengusaha. Dalam hal ini ada beberapa hal yang harus dipenuhi berkaitan dengan persoalan yaitu prinsip keadilan, kelayakan, dan kebajikan.

prinsip utama keadilan terletak pada Kejelasan aqad (transaksi) dan komitmen melakukannya. Aqad dalam perburuhan adalah aqad yang terjadi antara pekerja dengan pengusaha. Artinya, sebelum pekerja dipekerjakan, harus jelas dahulu bagaimana upah yang akan diterima oleh pekerja. Upah tersebut meliputi besarnya upah dan tata cara pembayaran upah. Khusus untuk cara pembayaran upah, Rasulullah bersabda yang diriwayatkan oleh Ibnu Majah dan Imam Thabrani : "Dari Abdillah bin Umar, Rasulullah Saw. Bersabda: "Berikanlah upah orang upahan sebelum kering keringatnya".

Dalam menjelaskan hadits itu, Syeikh Yusuf Qardhawi dalam kitabnya Pesan Nilai dan Moral dalam Perekonomian Islam, menjelaskan sebagai berikut:

Sesungguhnya seorang pekerja hanya berhak atas upahnya jika ia telah menunaikan pekerjaannya dengan semestinya dan sesuai dengan kesepakatan, karena umat Islam terikat dengan syarat-syarat antar mereka kecuali syarat yang mengharamkan yang halal atau menghalalkan yang haram. Namun, jika ia membolos bekerja tanpa alasan yang benar atau sengaja menunaikannya dengan tidak semestinya, maka sepatutnya hal itu diperhitungkan atasnya (dipotong upahnya) karena setiap hak dibarengi dengan kewajiban. Selama ia mendapatkan upah secara penuh, maka kewajibannya juga harus dipenuhi. Sepatutnya hal ini dijelaskan secara detail dalam "peraturan kerja" yang menjelaskan masing-masing hak dan kewajiban kedua belah pihak. Dengan demikian pemberian upah harus adil, sesuai ketentuan yang sudah di sepakati dan tidak ada yang tersakiti antra pekerja dan pemberi upah sehingga dapat memberikan manfaat antara satu dengan yang lainnya.

Sedangkan Kelayakan menuntut agar upah kerja cukup untuk memenuhi kebutuhan hidup minimum secara layak, layak bermakna cukup pangan, asndang dan papan, artinya upah harus mencukupi kebutuhan minimum dari ketiga kebutuhan yang merupakan kebutuhan dharuriyat, atau dasar. Layak bermaknsa sesuai pasaran. Islam menginginkan agar 
seorang pekerja menerima upah dengan layak, tidak kurang dari kebutuhan sehari-hari. Dan sesuai dengankebiasaan konsumsi masyarakt pada waktu itu.

Pemerintah menetapkan upah minimum sebagaimana dimaksud dalam pasal 88 ayat (3) huruf a undang-undang Nomor 13 Tahun 2003 tentang ketenagakerjaan berdasarkan kebutuhan hidup layak dan memperhatikan produktivitas dan pertumbuhan ekonomi. Dalam pasal 89 UU Nomor 13 Tahun 2003 upah minimum terdiri atas upah minimum berdasarkan wilayah provinsi atau kabupaten/kota dan upah minimum berdasarkan sektor pada wilayah provinsi atau kabupaten/kota.

Sedangkan Prinsip yang selanjutnya adalah prinsip kebajikan berarti menuntut agar jasa yang diberikan mendatangkan keuntungan besar kepada buruh.supaya bisa diberikan bonus.Dalam perjanjian kedua belah pihak diperingatkan untuk bersikap jujur dan adil dalam semua urusan mereka, sehingga tidak terjadi tindakan aniaya yang merugikan kepentingan pengusaha dan buruh.

Berdasarkan uraian di atas, maka dapat disimpulkan bahwa untuk mempertahankan upah pada suatu standar yang wajar, Islam memberikan kebebasan sepenuhnya dalam mobilitas tenaga kerja sesuai dengan perjanjian yang disepakati (akad). Agar hubungan kemitraan tersebut dapat berjalan dengan baik dan semua pihak yang terlibat saling diuntungkan, maka Islam mengaturnya secara jelas dan terperinci dengan hukum-hukum yang berhubungan dengan ijaratul ajir (kontrak kerja). Pengaturan tersebut mencakup penetapan ketentuan-ketentuan Islam dalam kontrak kerja antara pengusaha dan pekerja, dengan memperhatikan prinsip keadilan, kelayakan dan kebajikan.

\section{Indikator Penetapan Upah}

Sesuai amanat pasal 97 undang-undang nomor 13 Tahun 2003 tentang ketenagakerjaan, pada tanggal 23 oktober 2015 telah ditetapkan peraturan pemerintah nomor 78 Tahun 2015 tentang pengupahan . Peraturan pemerintah ini merupakan salah satu agenda pemerintah dalam rangka memberikan perlindungan hak-hak atas upah bagi pekerja/buruh dan kepastian berusaha bagi para pengusaha serta untuk mewujudkan pengupahan yang adil.

Faktor faktor pertimbangan dalam penetapan upah minimum Kota Palembang yaitu: 1) Kebituhan hidup layak (KHL). Komponen kebutuhan hidup layak (khl) merupakan salah satu pertimbangan dalam penetapan upah minimum yang dimulai tahun 2006, laporan komponen KHL dibuat setiap 1 bulan oleh disnaskertrans kota Palembang dan di usul ke disnskertrans provinsi Sumatera Selatan dan diajukan ke gubernur; 2) Pertumbuhan Ekonomi. Data mengenai tingkat inflasi nasional tahun berjalan dan pertumbuhan produk domestik bruto (PDB) tahun berjalan yang digunakan untuk menghitung upah minimum tahun 2016 bersumber dari bahan pusat statistik (BPS) yaitu :Tingkat inflasi nasional sebesar 6,83\% (enam koma delapan puluh tiga persen), Pertumbuhan PDB sebesar 4,67\% (empat koma enam puluh tujuh persen).

Ketika hukum positif menyatakan bahwa komponen kebutuhan hidup layak buruh berdasarkan perhitungan untuk pekerja lajang dalam sebulan dengan 3.000 kalori perhari. Dengan tujuh komponen yaitu makan minum, sandang, perumahan, pendidikan, kesehatan, transportasi dan rekreasi serta hiburan. Dalam pandangan Islam kebutuhan dasar dijamin oleh Negara. Karean hukum Islam yang menjamin eksistensinya, karena upah merupakan bagian 
dari perlindungan harta (al-mal) maka setiap individu dan masyarakat memiliki kewajiban untuk menjaga eksistensinya.

Berdasarkan hal tersebut upah yang layak adalah upah upah yang menciptakan individu dan masyarakat sejahtera. Konsep masyarakat sejahtera dalam perspektif Islam adalah tidak terpisahnya dari pembahasan maqasid al-syariah. Yang juga memiliki tujuan utama untuk menghadirkan maslahat bagi keselamatan 5 (lima) hal pokok yang tercakup dalam al-dharuriyah al-khams. Yaitu agama (al-din), jiwa (al-nafs), akal (al-aql), katurunan (al-nasl), dan harta (al-mal), yang masing-masing terkait dengan kebutuhan maianimal yang harus terpenuhi, agar keselamatan lima hal tersebut terjaga (Syaifullah, tt: 54).

\section{Ketentuan Upah Minimum Kota Palembang dalam Memenuhi kebutuhan Hidup Layak bagi Buruh di Kota Palembang Menurut Islam.}

Upah merupakan salah satu indikator kesejahteraan manusia, yaitu komponen utama dalam memenuhi kebutuhan hidup sehari-hari bagi pekerja/buruh. Dalam politik ekonomi Islam menyatakan adanya jaminan tercapainya pemenuhan semua kebutuhan primer (basic need) tiap orang secara menyeluruh (An-Nabhani, 2009: 52). Para pengusaha yang akan mempekerjakan seorang pekerja harus terlebih dahulu menjelaskan segala sesuatunya terkait dengan pekerjaan yang akan dilaksanakan, baik waktu, jenis pekerjaan dan upah kerja. penetapan ketentuan yang mengatur penyelesaian perselisihan yang terjadi antara pengusaha dan pekerja. Termasuk ketentuan yang mengatur bagaimana cara mengatasi tindakan kezaliman yang dilakukan salah satu pihak (pengusaha dan pekerja) terhadap pihak lainnya.

Demikian pula pihak pengusaha berkewajiban membayar upah pekerja dan menghormati transaksi kerja yang telah ditentukan, berdasarkan Undang-Undang yang berlaku serta tidak bisa bertindak semena-mena terhadap pekerja.

Islam sebagai agama yang bersifat universal dan sebagai rahmatan lil'alamin tidak saja mengatur hubungan yang vertikal juga mengatur hubungan horizontal. Yang menyeimbangkan antara kebutuhan hidup didunia dan akhirat. Islam dalam kaitannya ini memperkenalkan kepada manusia lima komponen hidup yang mejadi kepentingan bagi semua manusia. Hukum Islam dengan demikian berfungsi menjaga lima komponen dasar yaitu jiwa, akal pikiran, harta benda, kerukunan dan keyakinan beragama manusia.

Ada beberapa ketentuan yang akan menjamin diperlakukannya tenagakerja secara manusiawi, yaitu (Anto, 2003: 228): 1) Bangunan hubungan antara mu'ajir dan ajir adalah hubungan persaudaraan yang manuisawi secara menyeluruh, jadi hubungan ini merupakan suatu man to man, brothertly relationship, bukan men to material relationship; 2) Beban kerja dan lingkungan yang melingkupinya harus memperhatikan nilai-nilai kemanusiaan, bahkan manusia juga membutuhkan saat-saat tertentu untuk istirahat, santai serta bersosialisasi dengan lingkungannya. Adanya jaminan untuk menjalankan ibadah; dan 3) Tingkat upah minimum hendaklah mencukupi bagi pemenuhan kebutuhan dasar dari tenaga kerja. Semakin tinggi tingakat upah, tentu saja semakin baik bagi kesejahteraan tenaga kerja.

Dengan adanya upah membuat individu mampu membiayai kebutuhan hidup seharihari, dapat membeli barang dan jasa yang dibutuhkannya serta melakukannya aktifitas ekonominya baik tujuan dunia maupun tujuan akhirat. Dalam penetapan upah Islam memiliki nilai-nilai utama dalam memperoleh harta. Islam menegaskan ada cara-cara hubungan antara 
pengusaha dan pekerja yang sesuai dengan syari'at, yaitu menuju tegaknya kemaslahatan bersama. Mrnguntungakan semua pihak tanpa ada yang terzhalimi. Sementara islam memandang hubungan antara pekerja dan pengusaha merupakan hubungan kemitraan yang mempunyai tujuan bersama, mendapatkan manfaat dan keadilan yang sama.

Ketika hukum positif menyatakan bahwa komponen kebutuhan hidup layak buruh berdasarkan perhitungan untuk pekerja lajang dalam sebulan dengan 3.000 kalori perhari. Dengan tujuh komponen yaitu makan minum, sandang, perumahan, pendidikan, kesehatan, transportasi dan rekreasi serta hiburan. Dalam pandangan Islam kebutuhan dasar dijamin oleh Negara. Karean hukum Islam yang menjamin eksistensinya, karena upah merupakan bagian dari perlindungan harta (al-mal) maka setiap individu dan masyarakat memiliki kewajiban untuk menjaga eksistensinya.

Menurut Bapak Drs. Alisani Indra.Msi. selaku kepala seksi bidang hubungan industrial syarat kerja dan kesejahteraan pekerja beliau menyatakan bahwa mekanisme penetapan upah minimum di kota palembang adalah (Wawancara, 13 Nov 2016): Mula-mula dewan pengupahan daerah (DPD) terdiri dari birokrat, akademisi, buruh, dan pengusaha mengadakan rapat membentuk tim survey dan turun kelapangan mencari tahu harga sejumlah kebutuhan yang dibutuhkan oleh pegawai karyawan dan buruh. setelah survey ke beberapa pasar di kota palembang yang dianggap representatif diperoleh angka kebutuhan hidup layak di gunakan sebagai dasar penentu upah minimum berdasarkan kebutuhan hidup layak (KHL), selain ditinjau dari pertumbuhan ekonomi dan data inflasi. Dewan Pengupahan Daerah (DPD) mengusulkan Upah Minimum Kota (UMK) kepada gubenur untuk disahkan, komponen Kebutuhan Hidup Layak (KHL) digunakan sebgai salah satu dasar dari penentuan upah minimumberdasarkan hidup pekerja lajang (belum menikah) selain dari data statistik (Data Inflasi) serta pertumbuhan Ekonomi "

Hal yang sama diungkapkan oleh Hermansyah selaku direktur utama Asosiasi pengusaha Indonesia (APINDO) terkait mekanisme pengupahan Beliau juga menyatakan bahwa (Wawwancara 9 Des 2016): "Secara umum sekarang penetapan UMP mengacu pada UU no.13 tentang ketenagakerjaan dan PP No.78.”. Begitu juga yang dijelaskan oleh bapak R.M Edi Ali , SH selaku kepala bidang pengupahan provinsi. Menjelaskan (wawancara 5 Des 2016): "Mekanisme penetapan upah kota sama halnya dengan mekanisme penetapan Provinsi yang tertuang dalam Dalam Keppres No. 107 Tahun 2004 tentang Dewan Pengupahan, kelembagaan Dewan Pengupahan terdiri dari Dewan Pengupahan Nasional (Depenas), Dewan Pengupahan Propinsi (Depeprov) dan Dewan Pengupahan Kabupaten/Kota (Depekab/Depeko). Dan Mekanisme penetapan upah minimum di kota palembang dilakukan berdasarkan peraturan Pemerintah Nomor 78 Tahun 2015 tentang Pengupahan".

Sehubungan telah diundangkannya peraturan pemerintah (PP) Nomor 78 Tahun 2015 tentnag pengupahan. Dan dalam rangka penetapan upah minimum tahun 2016. Sesuai pasal 44 yat (1) dan ayat (2) pp No. 78 Tahun 2015. 23 oktober 2015, maka penetapan upah minimum Provinsi (UMP) dan upah minimum kabupaten kota UMK tahun 2016 menggunakan formula perhitungan upah minimum yaitu:

$\mathrm{Umn}=\mathrm{Umt}+(\mathrm{Umt} \times($ Inflasi $+\% \mathrm{PDBt}))$. (Keterangan : UMn : upah minimum yang akan ditetapkan, UMt : upah minimum tahun berjalan, Inflasi : Inflasi yang dihitung dari periode september tahun berjalan, PDBt: pertumbuhan produk domestik bruto yang dihitung 
dari pertumbuhan produk domestik bruto yang mencakup periode kwartal III dan IV tahun sebelumnya dan periode kwartal I dan II tahun berjalan).

Berdasarkan hal tersebut upah yang layak adalah upah upah yang menciptakan individu dan masyarakat sejahtera. Konsep masyarakat sejahtera dalam perspektif Islam adalah tidak terpisahnya dari pembahasan maqasid al-syariah. Yang juga memiliki tujuan utama untuk menghadirkan maslahat bagi keselamatan 5 (lima) hal pokok yang tercakup dalam al-dharuriyah al-khams. Yaitu agama (al-din), jiwa (al-nafs), akal (al-aql), katurunan (al-nasl), dan harta (al-mal), yang masing-masing terkait dengan kebutuhan minimal yang harus terpenuhi, agar keselamatan lima hal tersebut terjaga (Syaifullah, 2008: 54).

Sedangkan Penangguhan Pelaksanaan Upah Minimum Kota Palembang. Jika Perusahaan yang tidak mampu membayar Upah Minimum Kota kepada Gubernur melalui Disnaker selambat-lambatnya 10 hari sebelum berlaku, dapat mengajukan permohonan penangguhan dengan cara:

Mengajukan penangguahan dengan melampirkan permohonan dengan gubenur $\mathrm{Cq}$. Dinasker Provinsi.

Syarat-syarat pengajukan penangguhan UMK yaitu; 1) Naskah asli kesepakatan antara Pengusaha dengan Serikat Pekerja/Serikat Buruh atau pekerja/buruh perusahaan yang bersangkutan; 2) Laporan keuangan perusahaan terdiri dari neraca rugi/laba beserta penjelasannya untuk 2 tahun terakhir; 3) Salinan akta pendirian perusahaan; 4) Dasar upah menurut jabatan pekerja/buruh; 5) Jumlah pekerja dan jumlah pekerja yang dimohonkan penangguhan; 6) Perkembangan produksi dan pemasaran selama 2 tahun terakhir serta rencana produksi dan pemasaran 2 tahun yang akan datang; dan ) Surat pernyataan kesediaan perusahaan untuk melaksanakan UMK yang terbaru setelah berakhirnya waktu penangguhan tersebut.

Permohonana penangguhan UMK diajukan oleh perusahaan paling lambat 10 (sepuluh) hari sebelum berlakunya ketetapan UMK.

\section{Implikasi Upah Minimum Kota Palembang terhadap Kesejahteraan Buruh.}

Problematika buruh sebenarnya tidak hanya sebatas upah, jauh lebih kepada permasalahan kesejahteraan yang diberikan oleh pihak-pihak penguasa kepada para pekerjaanya. Kesejahteraan (maslahah) dalam hal ini merupakan pencapaian seseorang kepada tingkat pemenuhan kebutuhan yang standar tidak kurang dan tidak lebih, sehingga pola kehidupan menjadi stabil dengan tercapainya maslahah. Menurut al-Ghazali, kesejahteraan (maslahah) dari suatu msyarakat tergantung kepada pencarian dan pemeliharaan lima tujuan dasar yaitu agama (ad-dien), hidup atau jiwa (nafs), keluarga atau keturunan (nasl), harta atau kekayaan (maal), dan intelek atau akal (aql). Ia menitikberatkan bahwa sesuai tuntutan wahyu kebaikan dunia akhirat merupakan tujuan utamanya (Karim, 2011: 62). 
Tabel 3

Perbandingan Komponen Kebutuhan Hidup Layak (KHL) Kota Palembang Dengan Kebutuhan Barang Dan Jasa Menurut Islam

\begin{tabular}{|c|c|c|c|c|}
\hline No & $\begin{array}{l}\text { Perbandingan Komponen } \\
\text { Kebutuhan Primer }\end{array}$ & $\begin{array}{l}\text { Hukum } \\
\text { Ketenagakerjaan }\end{array}$ & Hukum Islam & $\begin{array}{l}\text { Katagori dalam al- } \\
\text { Dharuriyatul al-Khams }\end{array}$ \\
\hline 1 & Makan dan minum & $\begin{array}{l}\text { Kebutuhan } \\
\text { primer }\end{array}$ & $\begin{array}{l}\text { Kebutuhan } \\
\text { primer } \\
\text { (dharuruyah) }\end{array}$ & Pemeliharaan jiwa \\
\hline 2 & Sandang & $\begin{array}{l}\text { Kebutuhan } \\
\text { primer }\end{array}$ & $\begin{array}{l}\text { Kebutuhan } \\
\text { primer } \\
\text { (dharuruyah) }\end{array}$ & Pemeliharaan jiwa \\
\hline 3 & Perumahan & $\begin{array}{l}\text { Kebutuhan } \\
\text { primer }\end{array}$ & $\begin{array}{l}\text { Kebutuhan } \\
\text { primer } \\
\text { (dharuruyah) }\end{array}$ & Pemeliharaan jiwa \\
\hline 4 & Pendidikan & $\begin{array}{l}\text { Kebutuhan } \\
\text { primer }\end{array}$ & $\begin{array}{l}\text { Kebutuhan } \\
\text { primer } \\
\text { (dharuruyah) }\end{array}$ & Pemeliharaan akal \\
\hline 5 & Kesehatan & $\begin{array}{l}\text { Kebutuhan } \\
\text { primer }\end{array}$ & $\begin{array}{l}\text { Kebutuhan } \\
\text { primer } \\
(\text { dharuruyah })\end{array}$ & Pemeliharaan jiwa \\
\hline 6 & Rekreasi dan Tabungan & $\begin{array}{l}\text { Kebutuhan } \\
\text { primer }\end{array}$ & $\begin{array}{l}\text { Kebutuhan } \\
\text { sekunder } \\
\text { (hajiyat) }\end{array}$ & $\begin{array}{l}\text { Pemeliharaan } \\
\text { Harta }\end{array}$ \\
\hline 7 & Ibadah & $\begin{array}{l}\text { Kebutuhan } \\
\text { sekunder }\end{array}$ & $\begin{array}{l}\text { Kebutuhan } \\
\text { primer } \\
\text { (dharuruyah) }\end{array}$ & Pemeliharaan agama \\
\hline 8 & Pernikahan & $\begin{array}{l}\text { Kebutuhan } \\
\text { sekunder }\end{array}$ & $\begin{array}{l}\text { Kebutuhan } \\
\text { primer } \\
\text { (dharuruyah) }\end{array}$ & $\begin{array}{l}\text { Pemeliharaan } \\
\text { keturunan }\end{array}$ \\
\hline 9 & Tranportasi & $\begin{array}{l}\text { Kebutuhan } \\
\text { Primer }\end{array}$ & $\begin{array}{l}\text { Kebutuhan } \\
\text { primer } \\
\text { (dharuruyah) }\end{array}$ & - \\
\hline
\end{tabular}

Sumber data yang diolah berdasarkan perbandingan data kebutuhan hidup layak dengan kebutuhan barang dan jasa menurut Islam Mekanisme Penetapan Upah Minimum Kota Palembang.

Menurut Imam al Ghazali aktifitas ekonomi merupakan bagian dari kewajiban sosial masyarakat yang sudah ditetapkan Allah Swt, apabila hal ini tidak dipenuhi, kehidupan dunia akan runtuh dan kehidupan umat manusia akan binasa. al-Ghazali merumuskan tiga alasan mengapa seseoarang harus melakukan aktivitas ekonomi. Pertama untuk memenuhi kebutuhan hidup yang bersangkutan, Kedua mensejahterakan keluarga, dan ketiga membantu orang lain yang membutuhkan.

Dari tiga kreteria di atas, membuktikan bahwa kesejahteraan seseorang akan terpenuhi apabila tingkat kebutuhan mereka tercukupi. Sebenarnya kesejahteraan dalam tataran teori 
memiliki banyak dimensi pengapilkasiannya, namun dalam hal ini lebih difokuskan kepada terpenuhnya kesejahteraan sesorang berdasarkan tingkat kebutuhannya.

Kenyataan di lapangan dilihat dari beberapa informan yang diwawancari memberikan penjelasan mengenai Upah Kota Palembang terhadap Kesejahteraan mereka. Dalam penetapan upah minimum Kota saat ini belum memberikan kesejahteraan kepada buruh, apalagi ditetapkannya PP Nomor 78 Tahun 2015. Sangat-sangat terbatas sekali untuk memberikan pendapat-pendapat yang akan disampaikan (Wawancara, Ali hanafiah, 6 Desember 2016). Adapun penyataan dari bapak R.M Edi Ali, SH. menyatakan bahwa (Wawancara 5 Desember 2016): "Penetapan upah saat ini sudah memberikan kesejahteraan kepada buruh terkait peraturan pemerintah nomor 78 tahun 2015 sudah adil memberikan penetapan itu, dengan menggunakan inflasi dan pertumbuhan ekonomi serta upah yang paling tinggi dibanding dengan provinsi sumatera lainnya".

Dengan demikian dapat disimpulkan sebagian mengatakan dapat terlaksana kesejahteran pekerja dengan adanya upah yang diberikan oleh pengusaha kepada mereka, dilihat dari pencapaian kebutuhan dasar hidup pekerja sudah tercakup di dalamnya. Bahkan kebutuhan tambahan seperti komunikasi, transportasi dan pakaianpun sudah termasuk. Akan tetapi bagi pekerja yang sudah bekeluarga melihat penetapan upah Nomor 78 Tahun 2015 belum bisa memberikan kesejahteraan bagi mereka, dikarenakan pencapaian kebutuhan Hidup layak hanya dilihat dari kacamata untuk pekerja lajang.

\section{Kesimpulan}

Prinsip-prinsip pengupahan menurut Ekomomi Syari'ah adalah prinsip keadilan, prinsip kelayakan dan prinsip kebajikan. Ketentuan Upah Minimum Kota Palembang dalam memenuhi kebutuhan hidup yang layak bagi buruh di Kota Palembang menurut Islam sudah layak bagi pekerja/buruh lajang. Akan tetapi belum bagi pekerja yang sudah bekeluarga. Karena kebutuhan yang dibutuhkan bertambah. dilihat dari prinsip-prinsip dalam Ekonomi Syari'ah hanya memberikan keadilan dan kebajikan, sedangkan prinsip kelayakan belum terlihat pada penetapan upah Kota Palembang. Jadi belum sepenuhnya mengarah pada prinsip-prinsip Ekomomi Syari'ah.

Implikasi Upah Minimum Kota Palembang belum menjamin terhadap kesejahteraan pekerja/buruh. Karena dalam peraturan pemerintah nomor 78 tahun 2015 mengatur survei KHL 1 kali dalam 5 tahun mengakibatkan minimnya pekerja/buruh maupun pengusaha untuk mengemukakan pendaptnya atau keinginannya terhadap kebutuhan hidup layak. 


\section{Daftar Pustaka}

Afzalurrhman, Muhammad Sebagai Seorang Pedagang, Yayasan Swarna Bhumy :Jakarta, 2000.

Al- Ibrahimi, Muhammad U'qlah, Hawafijul al-A'mal Bainal Islam Wa al-Nazhoriyatil Wadhiyyah, Maktabah ar-Risalah al-Hadisah.

al-Ghazal, Abu Hamid, Ihya Ulumuddin, (Beirut: Dar an Nahdah t.t), Jilid 2.

al-Juhaili, Wahbah, 2005, al-Fiqh al-Islami Wa Adilatuhu, Dar al-Fikr al - Mua'sshim: Damaskus, Jilid V, Cet ke- 8.

--------, Wahbah, Fiqh Islam Wa adillatuhu, Gema Insani : Jakarta. 2011.

Akib, R.H.M. Sejarah dan Kebudayaan Palembang Adat Isitiadat Perkawinan di Palembang, Cet 2. 1975.

Anto, Hendrie, Pengantar Ekonomi Mikro Islam. Ekonosia, Jakarta. 2003.

Arikunto, Suharsimi, Prosedur penelitian serta pendekatan praktek, Rineka Cipta: Jakarta, 1991.

Fauziah, Ika Yunia Etika, Bisnis Dalam Islam, Kencana, : jakarta, 2013.

Ghazaly, Abdul Rahman dkk, Fiqh Muamalah, Kencana : Jakarta, 2010.

Hady Pradipta., Fiqh Muamalah., http;/hadypradipta. Blog. Ekonomi Syari'ah. net/ 24/ 05/ 18: 06/ 2013.

http///Ribunsumsel.Com,Palembang

http://sumsel.tribunnews.com/2015/12/28/mulai-1-Januari-2016-umk-palembang-jadi-rp$\underline{2294000}$. di akses pada tanggal 11 Februari 2016.

Iskandar, Muhaimin, membajak diladang mesin. Yawas : Semarang. 2004.

Karim, Adiwarman A. Ekonomi Mikro Islam, RajaGrafindo Persada: Jakarta, edisi ke-3, 2011.

Lembaran Negara RI Tahun 2015 Nomor 273, tambhan Lembaran Negara RI No. 5747.

Mas'adi, Gufron. Fiqh Muamalat Konstektual, RajaGrafindo Persada.: Jakarta, 2002.

Moekijat, Administrasi Gaji dan Upah, Mandar Maju: Bandung, 1987.

Muhammad, Etika Bisnis Islami, Akademi Menejemen Perusahaan YKPN : Yogyakarta, 2004.

Anoraga, Pandji. Menejemen Bisnis, Rineka Cipta \& Sekolah Tinggi Ilmu Ekonomi (STIE) Bank BPD Jateng : Jakarta, 1997. 